\title{
Restriction of body size spectra within species of deep-sea plankton
}

\author{
John Mauchline \\ The Scottish Association for Marine Science, PO Box No. 3, Oban, Argyll PA34 4AD, United Kingdom
}

\begin{abstract}
Studies of the population structure of deep-sea species of micronekton, especially crustaceans and fish, and of abyssal echinoderms and molluscs, suggest that modes in length/frequency histograms are often restricted to narrower ranges of body length than would be expected from population analyses of shelf or coastal congeners. This possible restriction is examined here by using the adult Stage VI copepodid of calanoid copepods of the genus Euchaeta. This stage represents the asymptotic body size of the species and is directly comparable between species. The depth range of the 10 most common Euchaeta species present in the Rockall Trough (NE Atlantic) was determined. Seasonal changes in the mean body size (prosome length) were significant in all species except E. sarsi. Mean annual prosome length and its standard deviation was determined for each species. In comparing species, the standard deviation, expressed as a percentage of the mean, decreased with increasing depth of the species. This reflected the decreasing prominence of a seasonal change in prosome length with increasing depth. Populations of shelf and coastal species of copepods generally showed much larger variations from their mean sizes than oceanic and deep-sea species. This decrease in variability in deep-sea species reflects the much less variable environment in which they live.
\end{abstract}

\section{INTRODUCTION}

Patterns of body growth in deep-sea organisms, both pelagic and benthic, have been of major interest in recent years (Gage \& Tyler 1991, Mauchline 1991). Rates of growth have been determined in a variety of species through analyses of length/frequency distributions in diverse organisms such as pelagic decapod, mysid and euphausiid crustaceans, fish, and epibenthic echinoderms and molluscs. The size structure of the populations often exhibits very distinct modes (Aizawa 1974, Mauchline 1986, 1991, Miya \& Nemoto 1986a, b, 1987, Gage \& Tyler 1991), sometimes even reflecting individual instars within the moulting sequence of crustaceans (Childress \& Price 1978, Bishop 1982). The modes often appear to have a narrower range of body length than in shallower- or shelf-living congeners. One possible explanation is narrower time intervals for hatching of the eggs giving rise to less variation in the resulting body lengths of the juveniles. A second explanation, reinforcing the first, is that the deep-sea environment is more homogeneous, not only in its physical characteristics but also in its biotic ones.
This implies that the size cohorts within populations of endemic species are expected to be narrower than those resulting in coastal or shelf environments.

The latter hypothesis is difficult to test using shrimplike crustaceans, fish, or echinoderms because of the difficulty of identifying comparable entities within their life histories. Calanoid copepods, however, are a suitable tool. They develop from the fertilized egg through a series of naupliar stages followed by copepodid stages. The terminal stage, Stage VI, is the sexually mature adult and represents the asymptotic body size. It is an integration of environmental effects on development and growth, constrained by a genetic component.

The body size of the adult copepod varies seasonally, with depth, and geographically (e.g. Adler \& Jespersen 1920, Ussing 1938, Sewell 1948, Marshall 1949, Wiborg 1954, Deevey 1960, 1964, El-Maghraby 1964, Gaudy 1972, Strømgren 1974, Moraitou-Apostolopoulou 1975, Bottrell \& Robins 1984). Sewell (1948) equated variation of adult size in a species with environmental temperature, and Sander \& Moore (1983) reviewed studies of this inverse relationship. These data, how- 
ever, are contradictory and the emphasis has changed to an examination of the primary importance of food and its effects on growth (Deevey 1960, 1966, Sander \& Moore 1983, Klein Breteler et al. 1990). Again the results are not entirely conclusive but suggest that regularly fluctuating environmental parameters, especially temperature and food, result in seasonal fluctuations in body size.

Seasonal fluctuations of environmental temperature are virtually absent at depths below about 800 to $1000 \mathrm{~m}$ in the Rockall Trough, northeastern Atlantic (Mauchline 1991). Food availability at these depths is seasonally enhanced through deposition of aggregated phytodetritus (Lampitt 1985, Rice et al. 1986, Zeitzschel 1986, Thiel et al. 1988, Tyler et al. 1992, Billett et al. 1983). The rate of deposition is rapid (Lampitt 1985) and no data are available on its residence time in the deep water column. Tyler et al. (1992) have demonstrated a direct link between the residence time of phytodetritus on the abyssal sea bed, along with the co-occurrence of fish carcasses, and seasonality in the reproductive biology of the seastar Plutonaster bifrons. There may be a dampening of the impact of this seasonal input to the food of pelagic organisms owing to it having a relatively short residence time in the water column.

The genus Euchaeta is represented by some 14 species resident in the water column. Size variation within species is examined here relative to their depth of occurrence and compared with that of coastal species of other genera.

\section{METHODS}

Time series samples of zooplankton were collected at approximately 2 mo intervals between July 1973 and March 1974 and between March 1975 and February 1976 centred on $55^{\circ} \mathrm{N}, 12^{\circ} 30^{\circ} \mathrm{W}$ in the Rockall Trough using a combination rectangular midwater trawl of $7 \mathrm{~m}^{2}$ and a $1 \mathrm{~m}^{2}$ mouth opening. The nets were fished open and these samples were used for studies of seasonal changes in body size. In addition, a multiple rectangular midwater trawl (RMT $8+1$ ) (Roe \& Shale 1979, Roe et al. 1980) was used to collect a vertical series of samples at $54^{\circ} 30^{\prime} \mathrm{N}, 13^{\circ} \mathrm{W}$ in August/ September 1979 to define the vertical distribution of the species. Samples were taken at $100 \mathrm{~m}$ depth intervals between the surface and $900 \mathrm{~m}$ depth by both day and night. Angel et al. (1982) concluded that there was no influence of downwelling daylight on the vertical migration of species at depths greater than $900 \mathrm{~m}$ and so hauls were taken at $200 \mathrm{~m}$ depth intervals between 900 and $1900 \mathrm{~m}$ irrespective of day or night. Full details of the samples taken are given by Hargreaves et al. (1984).
The following species of Euchaeta occurred in the samples from the trough:

E. abbreviata Park, 1978

E. acuta Giesbrecht, 1892

E. barbata Brady, 1883

E. bisinuata G. O Sars, 1907

E. bradyi With, 1915

E. gracilis G. O. Sars, 1905

E. hanseni With, 1915

E. incisa G. O. Sars, 1905

E. longissima Park, 1978

E. media Giesbrecht, 1888

E. norvegica Boeck, 1872

E. pseudotonsa Fontaine, 1967

E. sarsi Farran, 1908

E. scotti Farran, 1908

Prosome length was measured from the anterior point of the rostrum to the posterior lateral edge of the last prosome segment using a micrometer graticulc on a binocular microscope. One-way analysis of variance for samples of unequal size (Sokal \& Rohlf 1969) was used to test for seasonal variation in prosome length.

\section{RESULTS}

The species were identified in the vertical series of samples and the number per $1000 \mathrm{~m}^{3}$ of water filtered in each depth horizon determined. Four species, Euchaeta bradyi, E. incisa, E. longissima and E. media, were either absent or too rare in the samples to determine their vertical position in the water column. The vertical distribution of the adult females in the RMT 1 samples (Fig. 1) show that E. acuta, E. pseudotonsa and E. norvegica perform a diel vertical migration, entering the surface layer at night. Only 2 E. gracilis occurred at depths shallower than $500 \mathrm{~m}$ and they were in the night samples (Fig. 1); this species was found at night at the surface in other samples from the Trough and so does perform a vertical migration on occasion. The other 6 species do not migrate, none of them being found in the upper $900 \mathrm{~m}$ during the night and only a single E. barbata being recorded there during the day (Fig. 1). The mean depth of occurrence, during the day, and its standard deviation was calculated for each species and their distributions in the vertical water column are shown in Fig. 2. Although males occurred more rarely than females in the samples, their vertical distribution coincided with that of the females in each species.

The mean prosome length and its standard deviation was determined in each month for adult females of each species (Fig. 3). There were too few Euchaeta hanseni and E. bradyi (Table 1 ) in the seasonal samples to include them. A third species, E. longissima, although common throughout the rest of the year 


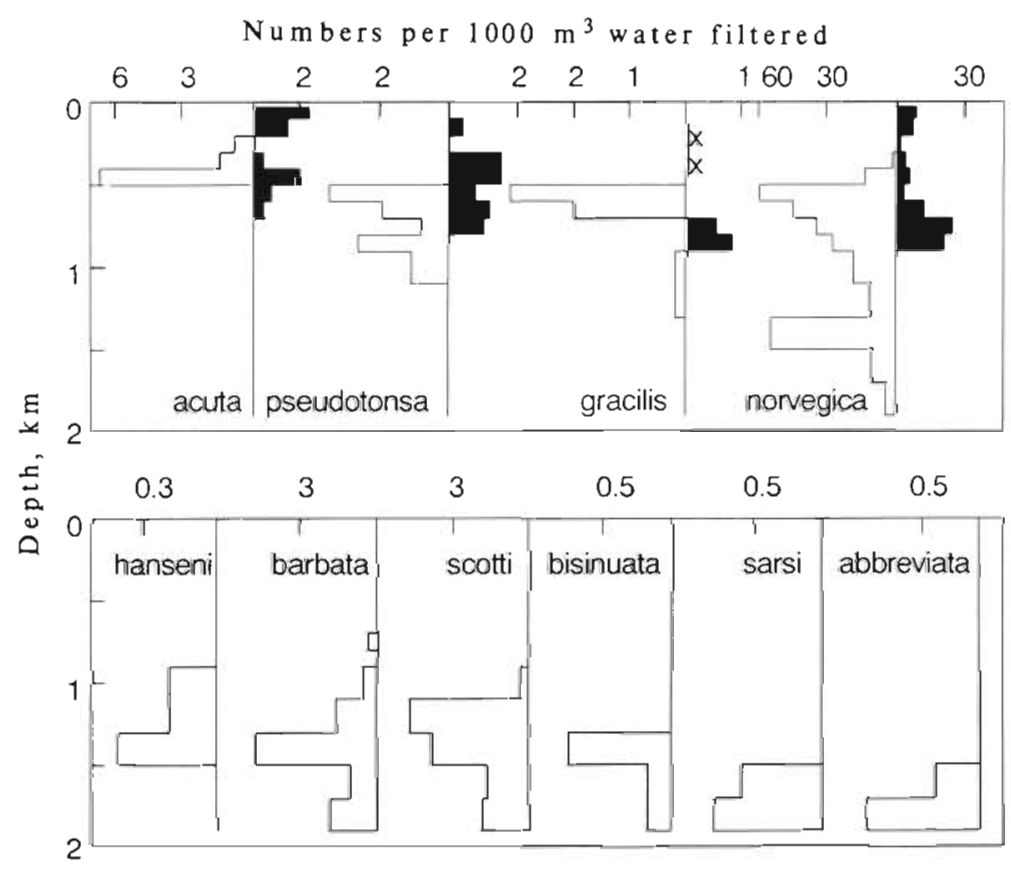

Fig. 1 Euchaeta species. Diel vertical distribution of adult females in the Rockall Trough. Black histograms: occurrence at depths shallower than $900 \mathrm{~m}$ at night; open histograms: occurrence in the total water column during the day. $X$ : Occurrence in low numbers

(Table 1), did not occur in the July samples and so was also not included. The 1-way analysis of variance shows that there is a significant seasonal change in mean prosome length in all species except $E$. sarsi (Table 2).

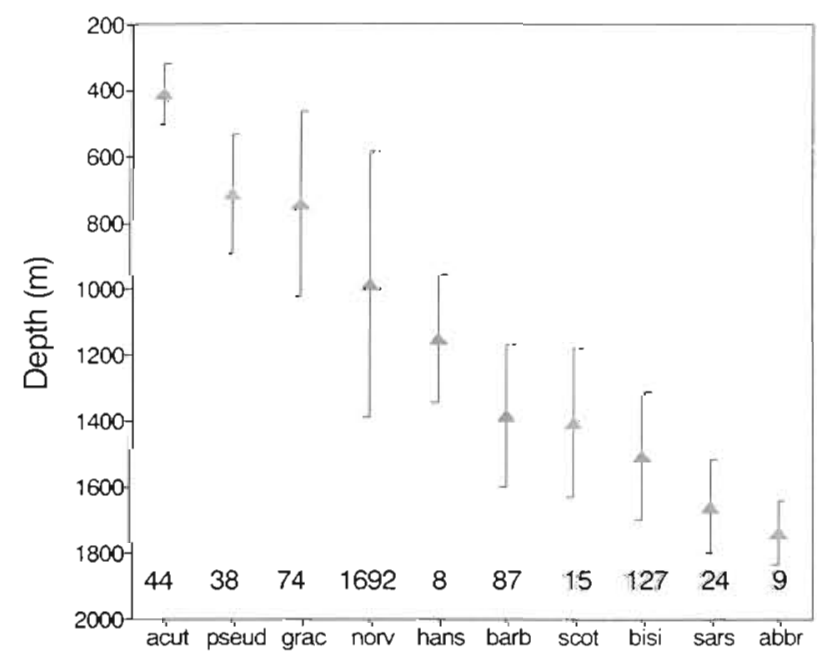

Fig. 2. Euchaeta species. Mean depth of occurrence $\pm \mathrm{SD}$ for adult females of each species, where sufficient numbers were available. acut $=E$. acuta; pseud $=E$. pseudotonsa; $\mathrm{grac}$ $=E$. gracilis; norv $=E$. norvegica; hans $=E$. hanseni; barb $=$ E. barbata; $s c o t=E$. scotti; bisi $=E$. bisinuata; sars $=E$. sarsi; abbr $=$ E. abbreviata
All samples of the females of each species were combined to calculate an annual mean prosome length and its standard deviation for each species (Table 1). These are weighted means since they reflect seasonal changes in abundance as well as seasonal changes in prosome length. The standard deviations are plotted as a percentage of mean annual prosome length (Fig. 4), a parameter that is independent of the body size of the species. One species, Euchaeta norvegica, is different from the rest $_{i}$ it has the largest vertical range of all the species (Figs. $1 \& 2$ ) and also the greatest overall variation in prosome length (Table 1). The other species show an inverse relationship between the amount of variation in prosome length and increasing depth of occurrence.

The prosome lengths of adult female Euchaeta norvegica were measured seasonally in a coastal population resident in Loch Etive (west coast of Scotland). The standard deviation as a percentage of the mean was 4.08 as compared with a corresponding value of 4.42 in the Rockall Trough in the years 1973 to 1975 . This implies that the Rockall Trough is a more variable environment for E. norvegica than Loch Etive.

Several authors have published raw data on seasonal frequencies of body length of a variety of species of calanoid copepods in coastal regions. Standard deviations expressed as a percentage of the mean sizes have been calculated and are plotted in Fig. 5 and contrasted with the comparable values for the Euchaeta species in the Rockall Trough. The Rockall Trough species all show lower values than the coastal species, E. norvegica in Loch Etive being an exception

\section{DISCUSSION}

The bathymetric distribution of Euchaeta species in the Rockall Trough, although only based on a single vertical series of samples, is supported by previous information on the vertical distribution of individual species (Farran 1926, Østvedt 1955, Roe 1972, 1974, 1984, Deevey \& Brooks 1977, Park 1978).

Mauchline (1992) infers that there is a seasonal trend in body size of Euchaeta barbata s. str. and E. barbata f. farrani. Analysis of variance validates this seasonality, as it does also for the other species except E. sarsi. Larger samples of $E$. sarsi might show a significant trend. The pronounced seasonality in prosome length 

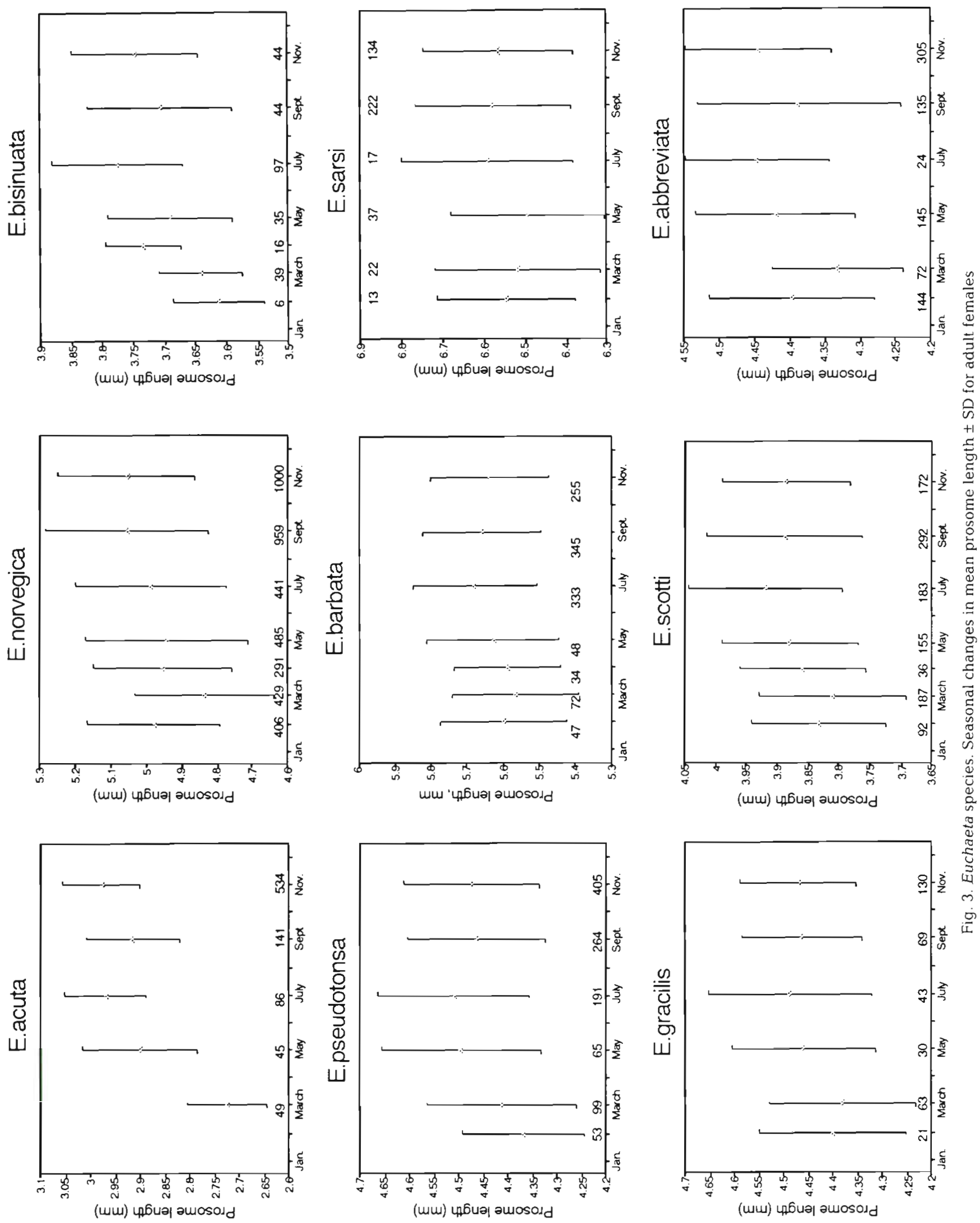
Table 1. Adult female Euchaeta species. Mean prosome length, its range, and the number (n) of individuals examined from the Rockall Trough

\begin{tabular}{|c|c|c|c|}
\hline \multirow[t]{2}{*}{ Species } & \multicolumn{2}{|c|}{ Prosome length in $\mathrm{mm}$} & \multirow{2}{*}{$\mathrm{n}$} \\
\hline & Mean & Range & \\
\hline E. acuta & 2.948 & $2.578-3.292$ & 869 \\
\hline E. pseudotonsa & 4.470 & $3.975-4.907$ & 1088 \\
\hline E. gracilis & 4.451 & $3.975-4.845$ & 358 \\
\hline E. norvegica & 4.997 & $4.348-5.839$ & 4011 \\
\hline E. hanseni & 6.337 & $5.652-6.832$ & 99 \\
\hline E. barbata & 5.647 & $4.845-6.087$ & 1136 \\
\hline E. scotti & 3.874 & $3.478-4.224$ & 1117 \\
\hline E. bisinuata & 3.726 & $3.478-4.099$ & 279 \\
\hline E. sarsi & 6.564 & $5.963-7.019$ & 447 \\
\hline E. abbreviata & 4.413 & $4.037-4.845$ & 825 \\
\hline E. longissima & 4.171 & $3.851-4.472$ & 679 \\
\hline E. bradyi & 6.189 & $5.714-6.894$ & 25 \\
\hline
\end{tabular}

Table 2. Presence of seasonal differences in mean prosome length within species of Euchaeta shown in Fig. 3 tested by ANOVA. The seasonal differences are significant in all species except E. sarsi

\begin{tabular}{|c|c|c|c|}
\hline & $\mathrm{df}$ & SS & $F$ \\
\hline \multicolumn{4}{|l|}{ E. acuta } \\
\hline Between months & 4 & 3.232 & \multirow{2}{*}{$114.7^{\circ}$} \\
\hline Within months & 850 & 5.991 & \\
\hline \multicolumn{4}{|l|}{ E. pseudotonsa } \\
\hline Between months & 5 & 1.229 & \multirow[t]{2}{*}{$11.9 \cdots$} \\
\hline Within months & 1071 & 22.099 & \\
\hline \multicolumn{4}{|l|}{ E. gracilis } \\
\hline Between months & 5 & 0.480 & \multirow[t]{2}{*}{$5.3^{\cdots}$} \\
\hline Within months & 350 & 6.389 & \\
\hline \multicolumn{4}{|l|}{ E. norvegica } \\
\hline Between months & 6 & 20.090 & \multirow[t]{2}{*}{$76.3 \cdots$} \\
\hline Within months & 4004 & 175.887 & \\
\hline \multicolumn{4}{|l|}{ E. barbata } \\
\hline Between months & 6 & 1.136 & \multirow[t]{2}{*}{$6.8 \cdots$} \\
\hline Within months & 1125 & 31.480 & \\
\hline \multicolumn{4}{|l|}{ E. scotti } \\
\hline Between months & 6 & 1.366 & \multirow[t]{2}{*}{$16.7^{\cdots}$} \\
\hline Within months & 1110 & 15.158 & \\
\hline \multicolumn{4}{|l|}{ E. bisinuata } \\
\hline Between months & 6 & 0.667 & \multirow[t]{2}{*}{$11.4^{\cdots}$} \\
\hline Within months & 274 & 2.678 & \\
\hline \multicolumn{4}{|l|}{ E. sarsia } \\
\hline Between months & 5 & 0.300 & \multirow[t]{2}{*}{1.7} \\
\hline Within months & 439 & 15.506 & \\
\hline \multicolumn{4}{|l|}{ E. abbreviata } \\
\hline Between months & 5 & 0.918 & \multirow[t]{2}{*}{$14.1 \cdots$} \\
\hline Within months & 819 & 10.699 & \\
\hline$\cdots p<0.001$ & & & \\
\hline
\end{tabular}

of $E$. acuta is reduced in the other species with depth. The reduction in the proportions of the standard deviations relative to the means found with depth is a func-

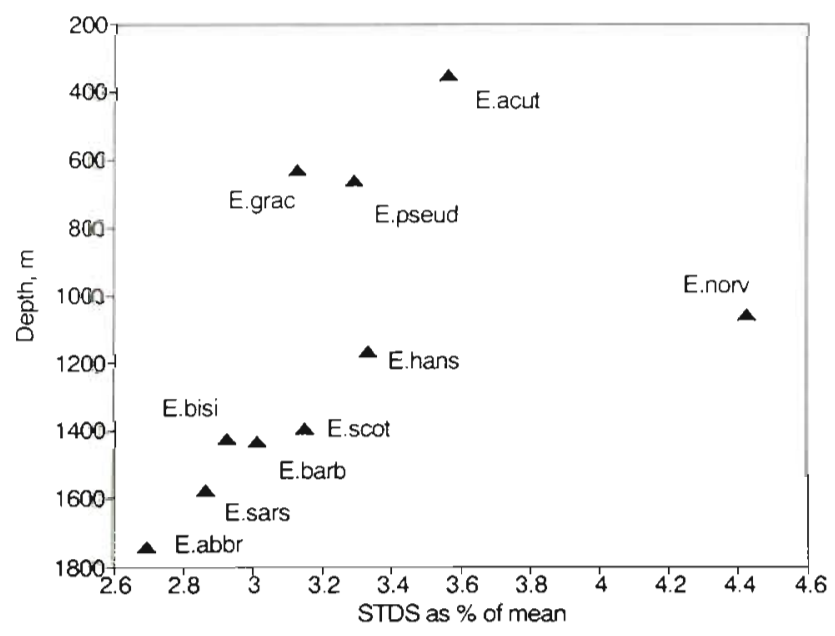

Fig. 4. Euchaeta species. Standard deviation of annual mean prosome length of adult females expressed as a percentage of the annual mean prosome length for each species and plotted relative to the mean depth of occurrence of each species as defined in Fig. 2

tion of this restriction of seasonal variability in prosome length. Coastal species such as Temora longicornis and Centropages hamatus exhibit very marked seasonal changes in mean prosome length within populations, reflected in their standard deviations. Seasonal changes in body size are caused by a complex of

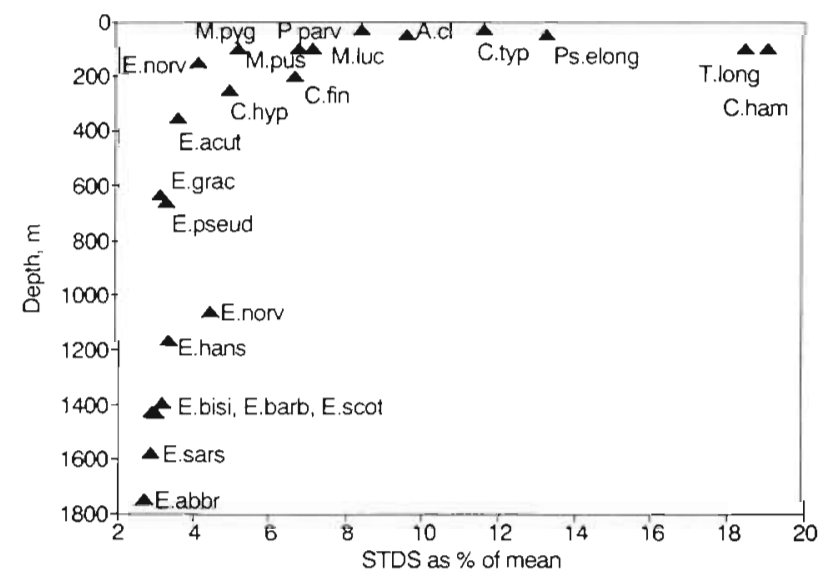

Fig. 5. Calanoid copepods. The data on the Euchaeta species in Fig. 4 are replotted along with comparable data derived from total body length measurements of coastal copepods supplied by various authors. A.cl = Acartia clausi (Marshall 1949); C.fin = Calanus finmarchicus (Adler \& Jespersen 1920 , Wiborg 1954); C.hyp = C. hyperboreus (Wiborg 1954); C.ham = Centropages hamatus (Marshall 1949); C.typ = C. typicus (Digby 1950); M.luc = Metridia lucens (Wiborg 1954); M.pus = Microcalanus pusillus (Wiborg 1954); M.pyg = M. pygmaeus (Marshall 1949); P.parv = Paracalanus parvus (Marshall 1949); Ps.elong $=$ Pseudocalanus elongatus (Marshall 1949, Wiborg 1954); T.long = Temora longicornis (Adler \& Jespersen 1920, Marshall 1949) 
factors, both physical and biotic. These act, in the case of coastal species of the genera Acartia. Centropages and Temora, on successive generations of these species within one breeding season (e.g. Gaudy 1972, Daro \& Gijsegem 1984). Species such as Calanus finmarchicus have fewer generations within a year than these small species but seasonal variation in size is still prominent.

The comparison of populations of Euchaeta norvegica between the Rockall Trough and Loch Etive showed that the latter was less variable. Loch Etive has an inner basin of maximum depth of $150 \mathrm{~m}$, E. norvegica being primarily confined to the deep water in this basin. Renewal of this deep water is aperiodic with a mean residence time of 1.3 yr (Edwards \& Edelsten 1977). Consequently, it lives in an environment with relatively stable physical conditions although biotic factors exhibit the normal seasonal fluctuations. Its vertical range in the Rockall Trough is from the surface to $1900 \mathrm{~m}$ (Fig. 1), with a small proportion of the population probably occurring even deeper. The vertical distribution is bimodal (Fig. 1) and there is a clear increase in mean prosome length of individuals with increasing depth (Table 3). This extreme vertical range, from the surface at night, to more than $2000 \mathrm{~m}$ depth is probably the source of this greater variation.

The 3 shallowest-living species, Euchaeta acuta, E. gracilis and E. pseudotonsa, perform a diel vertical migration. Their variation in prosome length (Figs. 4 $\& 5)$ is compatible with their bathymetric ranges and does not have a component ascribable to their diel vertical migrations.

These relatively large standard deviations in coastal species were expected. What was not foreseen is the regular decrease in the standard deviations with modal

Table 3. Euchaeta norvegica. Mean prosome length \pm SD of individuals in the different depth horizons of the vertical series of samples taken during the day; the numbers $(n)$ in the sample are given

\begin{tabular}{|cccc|}
\hline Depth horizon $(\mathrm{m})$ & Mean & $\mathrm{SD}$ & $\mathrm{n}$ \\
\hline $0-100$ & - & - & - \\
$100-200$ & - & - & - \\
$200-300$ & - & - & - \\
$300-400$ & 4.969 & - & 2 \\
$400-500$ & 4.881 & 0.183 & 78 \\
$500-600$ & 4.889 & 0.194 & 252 \\
$600-700$ & 4.828 & 0.207 & 152 \\
$700-800$ & 4.930 & 0.226 & 84 \\
$800-900$ & 5.022 & 0.216 & 85 \\
$900-1100$ & 5.006 & 0.205 & 105 \\
$1100-1300$ & 5.000 & 0.217 & 100 \\
$1300-1500$ & 5.107 & 0.216 & 287 \\
$1500-1700$ & 5.069 & 0.253 & 116 \\
$1700-1900$ & 5.199 & 0.320 & 27 \\
\hline
\end{tabular}

depth of occurrence exhibited by the deep-living, nonmigrating Euchaeta species (Fig. 4). Vertical migrators and non-migrators among the micronektonic shrimps and fish have different patterns of annual growth in body size (Mauchline 1991). Such a sharp distinction does not exist among the calanoid copepods (Figs. 4 \& 5). E. norvegica is exceptionally eurybathic, and this factor may, in itself, account for its larger than average standard deviation (Fig. 4). which is placed in a more general context in Fig. 5.

The regular decrease in the size spectra of species with depth may reflect a decreasing impact of the seasonal deposition of aggregated phytodetritus and other surface-derived detritus. Tyler et al. (1992) link this seasonal input with the seasonality in the reproductive patterns of the seastar Plutonaster bifrons. The detritus is deposited and accumulated on the abyssal floor and is available in utilizable concentrations to the seastars for some 4 to 8 wh (Gage \& Tyler 1991). Its impact in the water column probably decreases with increasing depth owing (1) to consumption on its passage downwards and (2) to shorter residence times in the depth horizons at utilizable concentrations. Further, Euchaeta species have the feeding appendages of carnivores rather than detritivores and so may not use this food source to any great extent, even if available.

The next step will be to examine the differing life history strategies of these Euchaeta species relative to their modal depth of occurrence. They might be expected to show a progression from complex responses in shelf and coastal environments, resulting in polymorphic populations, to a relatively simple population structure in the deep sea. These data beg the question as to whether a population parameter such as the standard deviation of the mean might act as a bioassay tool to relate variation in one environment or habitat with that in another.

Acknowledgement. The Scottish Association for Marine Science is financed by a Grant-in-Aid from the Natural Environment Research Council, Swindon.

\section{LITERATURE CITED}

Adler, G., Jespersen, P. (1920). Variations saisonnières chez quelques copépodes planctoniques marins. Meddr. Kommn Havunders., Plankton 2 (1): 1-46

Aizawa, Y (1974). Ecological studies of micronektonic shrimps (Crustacea, Decapoda) in the western North Pacific. Bull. Ocean Res. Inst. Tokyo 6: 1-84

Angel, M. V., Hargreaves, P. M., Kirkpatrick, P., Domanski, P. (1982). Low variability in planktonic and micronektonic populations at $1000 \mathrm{~m}$ depth in the vicinity of $42^{\circ} \mathrm{N} 17^{\circ} \mathrm{W}$ evidence against diel migratory behaviour in the majority of species. Biol. Oceanogr. 1. 287-319

Billett, D. S. M., Lampitt, R. S., Rice, A. L., Mantoura, R. F. V. 
(1983). Seasonal sedimentation of phytoplankton to the deep-sea benthos. Nature 302: 520-522

Bishop, J. D. D. (1982). The growth, development and reproduction of a deep-sea cumacean (Crustacea: Peracarida). Zool. J. Linn. Soc. 74: 359-380

Bottrell, H. H., Robins, D. B. (1984). Seasonal variations in length, dry weight, carbon and nitrogen of Calanus helgolandicus from the Celtic Sea. Mar. Ecol. Prog. Ser. 14: 259-268

Childress, J. J., Price, M. H. (1978). Growth rate of the bathypelagic crustacean Gnathophausia ingens (Mysidacea: Lophogastridae). I. Dimensional growth and population structure. Mar. Biol. 50: 47-62

Daro, M. H., Gijsegem, B. van (1984). Ecological factors affecting weight, feeding and production of five dominant copepods in the Southern Bight of the North Sea. Rapp. P.-v. Réun. Cons. int. Explor. Mer 183:226-233

Deevey, G. B. (1960). Relative effects of temperature and food on seasonal variations in length of marine copepods in some eastern American and western European waters. Bull. Bingham oceanogr. Coll. 17 (2): 54-86

Deevey, G. B. (1964). Annual variation in length of copepods in the Sargasso Sea off Bermuda. J. mar. biol. Ass. U.K. 44: $589-600$

Deevey, G. B. (1966). Seasonal variations in length of copepods in South Pacific New Zealand waters. Aust. J. mar. Freshwat. Res. 17:155-168

Deevey, G. B., Brooks, A. L. (1977). Copepods of the Sargasso Sea off Bermuda: species composition, vertical and seasonal distribution between the surface and $2000 \mathrm{~m}$. Bull. mar. Sci. 27: 256-291

Digby, P. S. B. (1950). The biology of the small planktonic copepods of Plymouth. J. mar. biol. Ass. U.K. 29: 393-438

Edwards, A., Edelsten, D. J. (1977). Deep water renewal of Loch Etive: a three basin Scottish fjord. Estuar. coast. mar. Sci. 5: 575-595

El-Maghraby, A. M. (1964). The seasonal variations in length of some marine planktonic copepods from the eastern Mediterranean at Alexandria. Crustaceana 8: 37-47

Farran, G. P. (1926). Biscayan plankton collected during a cruise of H. M. S. Research 1900. Part XIV The Copepoda. J. Linn. Soc., Zool. 36: 219-310

Gage, J. D., Tyler, P. A. (1991). Deep-sea biology. A natural history of organisms at the deep-sea floor. Cambridge University Press, Cambridge

Gaudy, R. (1972). Contribution a la connaissance du cycle biologique des copépodes du Golfe de Marseille. 2. Étude du cycle biologique de quelques espèces caractéristiques. Tethys $4: 175-242$

Hargreaves, P. M., Ellis, C. J., Angel, M. V. (1984). An assessment of the biological processes close to the sea bed in a slope region and its significance to the assessment of sea bed disposal of radioactive waste. Institute of Oceanographic Sciences, Wormley, U.K., Rept 185: 1-117

Klein Breteler, W. C. M., Schogt, N., Gonzalez, S. R. (1990). On the role of food quality in grazing and development of life stages, and genetic change of body size during cultivation of pelagic copepods. J. exp. mar. Biol. Ecol. 135: 177-189

Lampitt, R. S. (1985). Evidence for the seasonal deposition of detritus to the deep-sea floor and its subsequent resuspension. Deep Sea Res. 32: 885-897

Marshall, S. M. (1949). On the biology of the small copepods in Loch Striven. J. mar. biol. Ass. U.K. 28: 45-122

Mauchline, J. (1986). The biology of the deep-sea species of Mysidacea (Crustacea) of the Rockall Trough. J. mar. biol. Ass. U.K. 66: 803-824

Mauchline, J. (1991). Some modern concepts in deep-sea studies: patterns of growth in the different horizons. In:
Mauchline, J., Nemoto, T. (eds.) Marine biology, its accomplishment and future prospect. Hokusen-Sha Tokyo, p. $107-130$

Mauchline, J. (1992). Taxonomy, distribution and biology of Euchaeta barbata (= E. farrani) (Copepoda: Calanoida) Sarsia 77: 131-142

Miya, M., Nemoto, T. (1986a). Reproduction, growth and vertical distribution of the mesopelagic fish Cyclothone pseudopallida (family Gonostomatidae). In: Ueno, $T$., Arai, R., Taniguchi, T., Matsuura, K. (eds.) Indo-Pacific fish biology. Proceedings of the 2nd International Conference on Indo-Pacific Fishes. Ichthyological Society of Japan, Tokyo, p. 830-837

Miya, M., Nemoto, T (1986b). Life history and vertical distribution of the mesopelagic fish Cyclothone alba (family Gonostomatidae) in Sagami Bay, Central Japan. Deep Sea Res. 33: 1053-1068

Miya, M., Nemoto, T. (1987). Some aspects of the biology of the micronektonic fish Cyclothone pallida and C. acclinidens (Pisces: Gonostomatidae) in Sagami Bay, Central Japan. Bull. Tohoku Reg. Fish. Res. Lab. 26: 35-43

Moraitou-Apostolopoulou, M. (1975). Seasonal variations in length of three copepods in Saronic Bay (Greece). Boll. Pesca Piscic. Idrobiol. 30: 93-101

Østvedt, O. J. (1955). Zooplankton investigations from Weather Ship M in the Norwegian Sea, 1948-49. Hvalråd Skr. 40: 1-93

Park, T. (1978). Calanoid copepods (Aetideidae, Euchaetidae) from Antarctic and Subantarctic waters. In: Biology of Antarctic Seas 7. Antarct. Res. Ser. 27: 91-290

Rice, A. L., Billett, D. S. M., Fry, J., John, A. W. G., Lampitt, R. S., Mantoura, R. F. C., Morris, R. J. (1986). Seasonal deposition of phytodetritus to the deep-sea floor. Proc. R. Soc. Edinb. 88B: 265-279

Roe, H. S. J. (1972). The vertical distributions and diurnal migrations of calanoid copepods collected on the SOND cruise, 1965. IIl. Systematic account: families Euchaetidae up to and including the Metridiidae. J. mar. biol. Ass. U.K. 52: $525-552$

Roe, H. S. J. (1974). Observations on the diurnal vertical migrations of an oceanic animal community. Mar. Biol. 28: $99-113$

Roe, H. S. J. (1984). The diel migrations and distributions within a mesopelagic community in the north east Atlantic. 4. Copepods. Prog. Oceanogr. 13: 353-388

Roe, H. S. J., Shale, D. M. (1979). A new multiple rectangular midwater trawl (RMT $1+8 \mathrm{M}$ ) and some modifications to the Institute of Oceanographic Sciences' RMT 1+8. Mar Biol. 50: 283-288

Roe, H. J. S., Baker, A. de C., Carson, R. M., Wild, R., Shale, D. M. (1980). Behaviour of the Institute of Oceanographic Sciences' rectangular midwater trawls: theoretical and experimental observations. Mar. Biol. 56: 247-269

Sander, F., Moore, E. A. (1983). Physioecology of tropical marine copepods. I. Size variations. Crustaceana 44:83-93

Sewell, R. B. S. (1948). The free-swimming planktonic Copepoda. Geographical distribution. Scient. Rep. John Murray Exped. 8: 317-592

Sokal, R. R., Rohlf, F. J. (1969). Biometry. W. H. Freeman and Co., San Francisco

Stromgren, T. (1974). Zooplankton investigations in Skjomen 1969-1973. Astarte 7: 1-15

Thiel, H., Pfannkuche, O., Schriever, G., Lochte, K., Gooday, A. J., Memleben, Ch., Mantoura, R. F. G., Turley, C. M., Patching, A. W., Riemann, F. (1988). Phytodetritus on the deep-sea floor in a central region of the northeast Atlantic. Prog. Oceanogr. 6: 203-239 
Tyler, P. A., Gage, J. D., Paterson, G. J. L., Rice, A. L. (1992). Dietary constraints on reproductive periodicity in two sympatric deep-sea astropectinid seastars. Mar. Biol. (in press\}

Ussing, H. H. (1938). The biology of some important plankton animals in the fjords of East Greenland Meddr. Grønland $100(7): 1-108$

This article was submitted to the editor
Wiborg, K. F. (1954). Investigations on zooplankton in coastal and offshore waters of Western and Northwestern Norway with special reference to copepods. Rep. Norw. Fish. mar. Invest. 11: 1-246

Zeitzschel, B. (1986). The dynamics of organic production in the Rockall Channel area. Proc. R. Soc. Edinb. 88B: $207-220$

Manuscript first received: July 31, 1992

Revised version accepted: November 5, 1992 